\title{
SOLAR POWERED MOBILE POWER BANK SYSTEM
}

\author{
Srilakshmi.Ch \\ Assistant Professor, \\ Department of Information Technology, \\ R.M.D Engineering College, \\ Chennai, Tamilnadu, India \\ Rackland. S, Prasanth. B, Ragul .S, Prabhudeeswaran .G \\ UG Scholar, \\ Department of Information Technology, \\ R.M.D Engineering College, \\ Chennai, Tamilnadu, India
}

\begin{abstract}
The objective of this research is to design a Solar Powered Portable Power Bank for mobile phone using sunlight as its ultimate power, which can be used effectively during disaster events. It has in-built solar panel which converts the solar energy to electrical energy. The charge is then transferred to a battery for storage of charge for further use, with the battery having a microcontroller indicating the percent of charge present in the battery. The battery is connected to a charging circuit having an USB port as output to the respective Mobile phones.
\end{abstract}

KEYWORDS: Solar energy, Portable, Disaster recovery, Battery

\section{INTRODUCTION}

The major liability or drawbacks of communication lines comes because of the distortion of electrical lines or lack of generation of electricity as like in remote areas or during disaster or natural calamities. To set back such drawbacks, we need a renewable source of energy which can function round the clock without any disruption. Solar power bank is one of its kind. It works on the power of the sun, converting solar to electrical and helps in charging the cell phones which can be used in communication, and thus, turns to be vital during disasters and power outage.

\section{PROBLEM STATEMENT}

The major factor that drove us to this project is that it is one the method of charging that utilizes the renewable sources of energy where we can overcome the exhaustible usage of power and charge. It reduces the environmental pollution and is much user friendly. During disasters and power outages, it can be used with ease and with a long and forever durability of device and power. Even in the remote areas having scarcity of electricity, such models can be used. It can be a bit rusty during the rainy and foggy days and needs delicate care.

\section{PRODUCT ARCHITECTURE}

The power bank input and output are designed to compatible with universal series bus (USB) and this protects the system from any electrical surges while plug-in. The USB connectors are user friendly to connect with any portable electronic devices such as smart phones, cameras, tabs, etc. The block diagram of the operation of the power bank with major and minor components are shown in the Fig. 1.

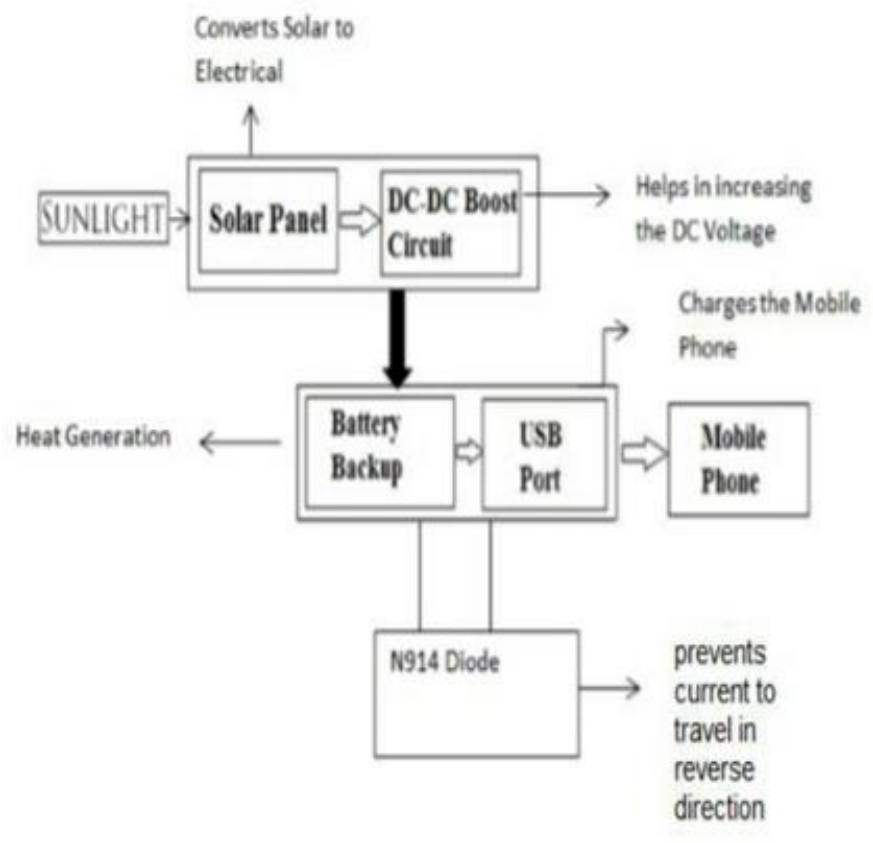

Fig 1: Architecture of solar energy conversion 


\section{International Journal of Engineering Applied Sciences and Technology, 2021 Vol. 6, Issue 1, ISSN No. 2455-2143, Pages 255-258 \\ Published Online May 2021 in IJEAST (http://www.ijeast.com)}

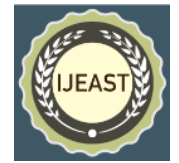

\section{TECHNICAL FEASIBILITY}

There are 2 main things to consider choosing a Solar panel or creating a Solar system. Battery capacity is measured in Amp Hours. The AH figure must be multiplied by the battery voltage to convert this to Watt Hours which is given by the simple calculation below.

$\mathrm{X} \times \mathrm{Y}=\mathrm{Z} \rightarrow(1)$

where, $\mathrm{X} \rightarrow$ Battery size in $\mathrm{AH}$

$\mathrm{Y} \rightarrow$ Battery Voltage

$\mathrm{Z} \rightarrow$ Power available in watt hours

However, as we know that we will not be able to power the battery once the voltage drops below our equipment's 150 American Journal of Electrical and Electronic Engineering requirements, that is why, we are never really able to take all the power from a battery. Lead acid batteries will give around $50 \%$ of their rated power and Li-ion batteries will give around $80 \%$ of their rated power. Solar panels are the most critical and final part in designing solar panels. The generation of power in a solar panel is measured in Watts (e.g. The power generation of part number STP010 in a solar cell is 10W). Theoretically, the energy that can be supplied to a battery can be calculated by multiplying the power generation rating of the solar panel (measured in Watts) to the number of hours the panel is exposed to sunshine.

A photovoltaic module can be defined as an assembly of 6x10 solar cells connected and packaged together. The solar array of a photovoltaic system which is generally comprised of these photovoltaic cells generate solar electricity and is used in domestic applications. Under standard test conditions, the DC output power of each module ranges between 100 to 365 watts. If the rated output of a solar panel remains the same, the efficiency is determined by the area of the module i.e. a $16 \%$ efficient $230 \mathrm{~W}$ solar module will consume half the area as that of a $8 \%$ efficient $230 \mathrm{~W}$ module. Only a few solar panels exceed an efficiency of over $19 \%$.

Most installations contain multiple modules as a single solar module generates only a limited amount of power. Some of the typical examples of photovoltaic systems are an array of solar modules, a solar inverter, a battery, a solar tracker and interconnection wiring. The photovoltaic panels present in solar-charged power banks can trickle-charge the internal battery of the system when placed in direct sunlight.

Depending on the capacity of the Power Bank and its current level of charge, it can take quite a while to fill up. For example, the time taken by a smartphone to charge completely is same as the time taken to charge a $1500 \mathrm{mAh}$ power bank completely. For larger banks, this charging time can be doubled, tripled or quadrupled. Most Power Banks use LED indicators to show whether these power banks are at capacity and a safety cut-off valve to avoid overheating and overcharging.

\section{ENGINEERING SOLUTONS}

In this paper, the product proposed meets the following requirements.

- It is a compact and lightweight to conserve resources.

- It achieves the top levels of energy conservation performance.

- It manages hazardous chemical substances.

- It is easily recycled at the end of life.

-Its parts reuse / reusability, disassembly / dismantling.

- It sustainably uses the renewable resources.

-It minimizes the use of number of interconnecting wires or cables.

\section{PHYSICAL PROTOTYPE}

The proposed system is solar based and solar panel plays a vital role in the experiment. Here, we have two solar panels each of $6 \mathrm{~V}$, for receiving the sunlight, which is connected to the battery of the system where the charge from the sun is stored for future use. The battery is also of $12 \mathrm{~V}$ with three $4 \mathrm{~V}$ battery connected in series. Then, the battery is connected to the mobile charging circuit which is further connected to a USB port from where a mobile can be connected for charging. There are two relay circuits, one attached between the solar panel and the battery and other one attached between the battery and the mobile phone which is controlled by the microcontroller. The microcontroller is the brain of the whole circuit as it checks and allows the required amount of flow of charge from one end to another. If at any point, we might get low or high voltages, then the microcontroller signals the relays and the relays cut the connection by switching off to protect the appropriate elements like the transistor, resistor etc. There are also LEDs attached at the solar panel side at the charging point for detection of flow of charge. There are also 4 LEDs to show the percentage of charge present in the battery.

When the solar panels are open, then sunlight direct falls on the photovoltaic cell of the panel and it converts the solar energy to electrical energy. The panel gives a voltage of $12 \mathrm{v}$ and the charge flows through the relay to the battery if the voltage is appropriate and is equal to the value set by the microcontroller to the battery. There is also a LED which displays the transfer of charge from the panel to the battery. When the battery is charged perfectly up to its full capacity, which is shown by the 4 LEDs connected to the battery through the microcontroller, the microcontroller shows the percentage of charge present in the battery and then we can connect a mobile phone at the end of the circuit. Here, we also attach a relay circuit which checks the flow of voltage. If we get low or high voltage, the relay switches off and the circuit becomes open.

With the appropriate charge, we can charge the mobile phone at the end of the circuit where we can get an USB port and the phone will be charged by connecting to the port. 


\section{International Journal of Engineering Applied Sciences and Technology, 2021 \\ Vol. 6, Issue 1, ISSN No. 2455-2143, Pages 255-258 \\ Published Online May 2021 in IJEAST (http://www.ijeast.com)}

After conducting the experiments, we concluded that in order to operate with high efficiency, we need to go through these selections: charging.

- We need bright and sunny weather for a better

- The panel wings should be placed under direct sunlight for better efficiency.

- We need two solar panels each of $6 \mathrm{~V}$ to power the battery.

- Simultaneously connecting the phone for charging and the battery being charged from the solar panels might take a longer time for the battery to charge.

- The microcontroller requires a $12 \mathrm{~V}$, so we need a battery minimum of $12 \mathrm{~V}$ for better operation.

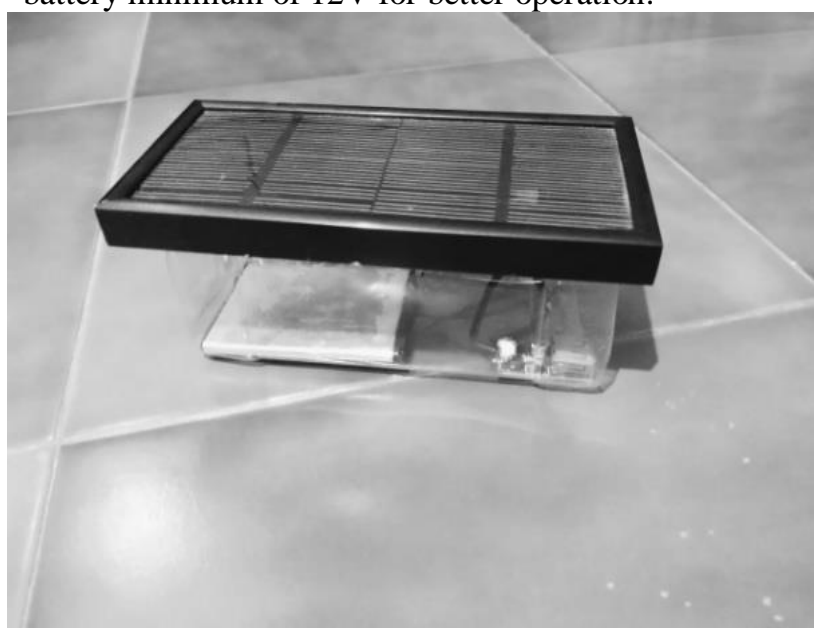

Fig 2: Mobile phone solar battery charger

\section{SUGGESTED IMPROVEMENTS}

We have chosen two solar panels instead of one to make it more portable and handier. A relay circuit has been added to improve the safety of the circuit, battery and the mobile phone. If the phone is undercharged or overcharged, the relay will cut the supply saving the battery and mobile from getting damaged. We have improvised the battery with an indicator integrated with a microcontroller which gives indication about the battery percentage.

\section{CONCLUSION}

Solar power banks are affordable, environment friendly, cost saving and reliable source of power supply for gadgets. The earth is already battling so many environmental hazards and global warming is the most glaring issue today. By using solar power, you will be conserving energy, thereby reducing the strain. This is because solar energy is pollution-free, it is clean, renewable energy. Its use doesn't promote the emission of greenhouse gases, unlike regular electricity, instead, you are only tapping sunlight on mother earth. If you have a lot of electronic gadgets, the chances are that you normally pay high electricity bills. Well, that can changes when you go for a solar power bank. Since you will not be using the regular electricity as much, your utility bill will reduce. After all, you are not paying for sunlight. Most importantly, it helps stay connected anytime, anywhere and on the go!

\section{REFERENCES}

[1] Shruti Sharma, Kamlesh Kumar Jain, Ashutosh Sharma a review on "Solar Cells: In Research and Applications",Materials Sciences and Applications, 2015, 6, 1145-1155 Published December 2015 http://dx.doi.org/10.4236/msa.2015.612113

[2]Askari Mohammad Bagher, Mirzaei Mahmoud Abadi Vahid, Mirhabibi Mohsen. "Types of Solar Cells and Application". American Journal of Optics and Photonics.Vol. 3, No. 5, 2015, pp. 94-113. doi: 10.11648/j.ajop.20150305.17

[3] N. Gupta, G. F. Alapatt, R. Podila, R. Singh, K.F. Poole, (2009). "Prospects of Nanostructure-Based Solar Cells for Manufacturing Future Generations of Photovoltaic Modules". International Journal of Photo energy 2009: 1. doi:10.1155/2009/154059.

[4] Ramachandra, T.V., Jain, R. and Krishnadasa, G. (2011) Hotspots of Solar Potential in India, 31783186.http://dx.doi.org/10.1016/j.rser.2011.04.007

[5]Shruti Sharma, Kamlesh Kumar Jain, Ashutosh Sharma a review on "Solar Cells: In Research and Applications",Materials Sciences and Applications, 2015, 6, 1145-1155 Published December 2015 http://dx.doi.org/10.4236/msa.2015.612113

[6]Khare, V., Nerma, S. and Baredar, P. (2013) Status of Solar Wind Renewable Energy in India. Renewable and Sustainable Energy Reviews, 27, 110.http://dx.doi.org/10.1016/j.rser.2013.06.018

[7] Askari Mohammad Bagher, Mirzaei Mahmoud Abadi Vahid, Mirhabibi Mohsen. "Types of Solar Cells and Application". American Journal of Optics and Photonics.Vol. 3, No. 5, 2015, pp. 94-113. doi: 10.11648/j.ajop.20150305.

[8] A.Sharma, (2011) A Comprehensive Study of Solar Power in India and World. Renewable and Sustainable Energy Reviews, 15, 1767-1776.

http://dx.doi.org/10.1016/j.rser.2010.12.017

[9] P.Raman, , J.Murali, , D.Sakthivadivel. and V.S Vigneswaran. (2012) Opportunities and Challenges in Setting 
Up Solar Photovoltaic Based Micro Grids for Electrification in Rural Areas of India. Renewable and Sustainable Energy Reviews, 16, 3320-3325.

http://dx.doi.org/10.1016/j.rser.2012.02.065

[10] S. Lal and A. Raturi, (2012) Techno-Economic Analysis of a Hybrid Mini-Grid System for Fiji Islands. International Journal of Energy and Environmental Engineering, 3, 10.

http://dx.doi.org/10.1186/2251-6832-3-10

[11] Zweibel, K. (2010) Should Solar Photovoltaics Be Deployed Sooner Because of Long Operating Life at Low, Predictable Cost? Energy Policy, 38, 7519-7530.

http://dx.doi.org/10.1016/j.enpol.2010.07.040

[12] Sharma, P. and Harinarayana, T. (2013) Solar Energy Generation Potential along National Highways. International Journal of Energy and Environmental Engineering, 4, 16.

http://link.springer.com/article/10.1186\%2F2251-6832-4-16

[13] Din?er, F. (2011) Overview of the Photovoltaic Technology Status and Perspective in Turkey. Renewable and Sustainable Energy Reviews, 15, 3768-3779.

http://dx.doi.org/10.1016/j.rser.2011.06.005

[14] Bhutto, A.W., Bazmi, A.A. and Zahedi, G. (2012) Greener Energy: Issues and Challenges for Pakistan-Solar Energy Prospective. Renewable and Sustainable Energy Reviews, 16, 2762-2780.

http://dx.doi.org/10.1016/j.rser.2012.02.043

[15] Maryanto Hendra Listrik Pada Ruang Kuliah Lantai 4 Gedung FTI ICoGOIA 2018 IOP Conf. Series: Materials Science and Engineering 621 (2019) 012008 IOP Publishing doi:10.1088/1757-899X/621/1/012008 7 UII

[16] Book of "Wind and Solar Power Plants" by Mukund Patel, CRC Press

[17] Book of "Solar Energy" by Dr. S. P. Sukhatme. Tata McGraw Hill Publication 